\title{
BACTERIAL AGGLUTINATION BY A LECTIN FROM THE LEAVES OF THE MEDICINAL PLANT, PIMENTA DIOICA (L.) MERR
}

\author{
SURYA P. H., ELYAS K. K., DEEPTI MADAYI ${ }^{*}$ \\ Department of Biotechnology, University of Calicut \\ Email: mdeepti81@gmail.com
}

Received: 18 May 2017 Revised and Accepted: 05 Mar 2018

\begin{abstract}
Objective: The current investigation involves the purification, characterization of the lectin from the leaves of Pimenta dioica (L.) Merr. (Myrtaceae) a medicinal plant, and its application in bacterial typing.

Methods: A lectin was purified from the leaves by cation exchange chromatography. SDS PAGE revealed the molecular weight of the purified lectin. Biochemical characterization was carried out by performing various tests. Hemagglutination inhibition was conducted to detect the sugar specificity. Additionally, bacterial agglutination was performed to predict whether the purified lectin was able to agglutinate the bacterial strains.

Results: SDS PAGE analysis revealed the lectin to be a tetramer in the range of 43-66 $\mathrm{kDa}$. The purified lectin agglutinated human, avian, and mouse erythrocytes, and was inhibited by $125 \mathrm{mmol}$ of mannose and xylose. The lectin was stable at $0-60{ }^{\circ} \mathrm{C}$ for 30 min and was unaffected by either 2 Mercaptoethanol (2-ME) or Dithiothreitol (DTT) $(50-250 \mu \mathrm{M})$. A pH of 6.0-8.0 was found optimum for its activity and was nearly independent of metal ions. The purified lectin contained about $20 \%$ carbohydrate as estimated by Anthrone method. Purified lectin agglutinated the Gram-negative Escherichia coli and Proteus vulgaris.
\end{abstract}

Conclusion: The isolated lectin was found to possess significant hemagglutinating activity. Due to its ability to agglutinate Gram negative bacteria such as Escherichia coli and Proteus vulgaris, it could be used for bacterial typing and for the design of bacterial filters.

Keywords: Pimenta dioica (Linn.) Merill, Myrtaceae, Erythrocytes, Lectin, Cation exchange chromatography, Bacterial agglutination

(C) 2018 The Authors. Published by Innovare Academic Sciences Pvt Ltd. This is an open access article under the CC BY license (http://creativecommons.org/licenses/by/4.0/) DOI: http://dx.doi.org/10.22159/ijpps.2018v10i4.20068

\section{INTRODUCTION}

"Lectin" has been derived from the Latin word "Legere", which means "to select", by William Boyd [1]. Lectins are a heterogeneous class of carbohydrate-binding proteins or glycoproteins of non-immune origin and are capable of specific recognition, and reversible binding to carbohydrates without altering their covalent structure or precipitate glycoconjugates [2]. Lectins were isolated from microorganisms, mushrooms and also from animals, even though it was initially found and described in plants [3]. They possess the ability to agglutinate erythrocytes with known carbohydrate specificity as they have at least one non-catalytic domain that binds reversibly to specific monosaccharides or oligosaccharides [4] either free in solution or on cell surfaces and the cell surface containing the carbohydrate conjugate act as the lectins receptor.

The sugar specificity of lectin is determined by a hapten inhibition test in which various sugars will be tested for their capacity to inhibit hemagglutination of erythrocytes. Agglutination assays are mostly applied for multivalent lectins as only they can agglutinate erythrocytes. Due to its sugar specificity affinity chromatography is mostly employed for lectin purification [5] which makes use of sugarbased polymers like Sephadex (glucose), Sepharose (galactose), Chitin (N-acetyl-glucosamine), or Glycoprotein linked matrices [6].

The biological role of lectins includes sugar transport or carbohydrate storage in plants, binding of symbiotic rhizobia to form root nodules, microbial adhesion [7] and provide resistance to microbial diseases. Some of the lectins have been used to fractionate $\mathrm{B}$ and $\mathrm{T}$ lymphocytes, to demonstrate changes in cell surface architecture following virus or parasitic infection, [8] as a carrier for the delivery of chemotherapeutic agents and for investigating cell surface receptors in bacteria, protozoa, and higher organisms for typing and characterization including that of bacteriophages receptors. They can be used for diagnostic as well as therapeutic purposes and are also known for their insecticidal, anti-microbial, anti-cancerous, anti-viral and immunomodulatory properties [9-12].
Pimenta dioica (Linn.) Merill belongs to the family Myrtaceae and is also known as "Allspice". It has been proved that certain plants belonging to Myrtaceae family have potential antioxidant activity due to the presence of several phytochemical constituents [13]. The plant is well known for its berries called Pimento which possesses an aromatic taste and flavor resembling a mixture of cinnamon, cloves and nutmeg and hence the name allspice $[14,15]$. The dried, green-mature fruit is the commercial flavoring and curing agent. Traditionally, a water extract of the berries is used to treat flatulence and diarrhea, as an adjuvant to tonics and purgatives and as an anodyne against rheumatism and neuralgia [16]. The therapeutic properties of the essential allspice oils are anesthetic, analgesic, antimicrobial, antioxidant, antiseptic, acaricidal, carminative, muscle relaxant, rubefacient, stimulant and tonic. The present study involved the screening of plants for the presence of novel lectins with good yield and activity. The study then focused on the aqueous extract of the leaves of Pimenta dioica (L.) Merr for the purification of lectin, with the ability to agglutinate bacteria.

\section{MATERIALS AND METHODS}

Chemicals and reagents

Bovine Serum Albumin (BSA), periodic acid, and CM-cellulose (Sigma, product code-C0806) was purchased from Sigma-Aldrich (St Louis MO, USA). Amicon Ultra-4 K centrifugal filter (Merck, Product code-UFC801024) was obtained from Merck Millipore Ltd. Blood bags for the purpose of hemagglutination was procured from Malabar Institute of Medical Science (MIMS) Hospital, Calicut. All the other reagents used were of analytical grade.

\section{Procurement of plant material and preparation of crude extract}

Plants were collected from the Calicut University Botanical Garden, $\left(11^{\circ} 08^{\prime} 02.01^{\prime \prime} \mathrm{N} 75^{\circ} 53^{\prime} 26.28^{\prime \prime} \mathrm{E}\right)$ and a specimen were deposited in the Calicut University Herbarium with a voucher number-6916. The leaves were air dried. Dried leaves were sheared into small pieces 
and $5 \mathrm{~g}$ of each leaf type was soaked in $20 \mathrm{ml}$ of Phosphate Buffered Saline (PBS, pH 7.4) for an overnight incubation at $4{ }^{\circ} \mathrm{C}$. Homogenate was filtered and centrifuged at $8000 \mathrm{rpm}$ for $30 \mathrm{~min}$. The supernatant was collected and stored at $4{ }^{\circ} \mathrm{C}$ to check the property of hemagglutination.

\section{Hemagglutination assay}

Hemagglutination activity of the crude was determined according to Ynalvez et al. [17]. The blood sample was kindly provided by MIMS Hospital, Calicut and by volunteers. $50 \mu \mathrm{l}$ of the supernatant (Crude) was subjected to serial twofold dilutions in PBS using a $\mathrm{U}$ or $\mathrm{V}$ bottom microtitre plate and was incubated with an equal volume of $2 \%$ erythrocyte suspension at room temperature for $30 \mathrm{~min}$. The crude which exhibited a higher titer value for hemagglutination was selected for further studies. Hemagglutination titer is defined as the reciprocal of the highest dilution positive for hemagglutination and is expressed as 1 hemagglutination unit.

\section{Purification of a lectin from plant extract}

Crude extract of leaves was prepared as described above. Three saturations of ammonium sulphate in the range $0-90 \%$ were used to fractionate proteins in the crude extract and the fractions were dialyzed against $0.1 \mathrm{X}$ PBS for $24 \mathrm{~h}$ at $4{ }^{\circ} \mathrm{C}$ with a minimum of 4 buffer changes and concentrated on lyophilization. Hemagglutination activity and titer of each dialyzed fractions were analyzed as described previously. Protein concentration was estimated using the Bradford assay [18] with Bovine Serum Albumin (BSA) as a standard and specific activity was determined. Specific activity is expressed as the number of hemagglutination units per mg protein.

Ion Exchange Chromatography was performed by using CMcellulose [Sigma, product code-C0806]. Hemagglutination property of column fractions was assessed as described previously and the fraction containing hemagglutinins was concentrated using Amicon ultra-4 $10 \mathrm{~K}$ centrifugal filter devices with a molecular weight cut off of 10 KDa (Merck, Product code-UFC801024).

\section{Validation of lectin purity by PAGE}

Polyacrylamide gel electrophoresis (PAGE) of the protein preparation was done according to Laemmli [19] with some modifications. The protein bands were visualized using Coomassie Brilliant Blue and silver nitrate staining as described by Rosenberg [20].

\section{Estimation of carbohydrate content}

The Molish's test was performed as described by Sadasivam (1985) to detect the presence of carbohydrates in the purified lectin sample [21] and was estimated by Anthrone method as described by Hedge and Hofreiter [22] with some modifications. Glucose was used as the standard.

\section{Periodic acid schiff (PAS) staining}

Presence of glycoprotein in the electrophoresed gel was analyzed by the method of Laija et al. [23] with some modification. The electrophoresed gel was immersed in $12.5 \%$ Trichloroacetic acid (TCA-w/v) for $30 \mathrm{~min}$ and rinsed lightly with distilled water for 15 seconds. Gel was then incubated in $1 \%$ periodic acid in $3 \%$ acetic acid solution, for $30 \mathrm{~min}$ and washed extensively with distilled water. The gel was immersed in Schiff's reagent and then allowed to develop color in the dark at $4{ }^{\circ} \mathrm{C}$. The appearance of a dark pink color in almost $50 \mathrm{~min}$ indicates the presence of a glycoprotein. The gel was then washed in freshly prepared $0.5 \%$ sodium metabisulphite $(\mathrm{w} / \mathrm{v})$ and kept for a final overnight incubation in distilled water. $3 \%$ acetic acid solution was used to store the gel. Immunoglobulin was used as positive control and Bovine Serum Albumin as a negative control.

\section{Hemagglutination inhibition assay}

The carbohydrate-binding specificity of the purified lectin was studied in accordance with a modified method of Pla et al. [24]. The various simple sugars used were Mannitol, Rhamnose, D-Arabitol, mannose, D-melibiose, N-acetyl galactosamine, Fucose, N-acetyl Glucosamine, Xylose, lactose, fructose, sorbitol, D-arabinose, and Dgalactose.

A serial twofold dilutions of each sugar (25 $\mu$ from $1 \mathrm{M}$ stock) were prepared with $1 \mathrm{X}$ PBS in microtiter plates. A stock of purified lectin with 4 hemagglutination unit was prepared in 1X PBS. $25 \mu$ l of the lectin preparation was added to each well and incubated at room temperature for 1 hour. $50 \mu \mathrm{l}$ of $2 \%$ erythrocyte suspension was added to each well and incubated for $30 \mathrm{~min}$ at room temperature. Wells without any sugar served as negative control. A positive reaction in which agglutination is inhibited by sugar is indicated by the presence of a distinctive red button on the bottom of the microtiter plate well.

\section{Determination of blood group specificity of the lectin}

The ability of the isolated lectin to agglutinate various blood types ( $2 \%$ solution of Human $A+, B+, O+a n d A B-R B C$, Chicken RBC, and Mice RBC in PBS) was analyzed as described previously.

\section{Effect of temperature on the stability of lectin}

Temperature stability of the lectin was analyzed as described by Tomohiro et al. [23] with minor modifications. $30 \mu \mathrm{l}$ aliquots of lectin were incubated at various temperatures: $-20^{\circ} \mathrm{C}, 4^{\circ} \mathrm{C}, 20^{\circ} \mathrm{C}, 40$ ${ }^{\circ} \mathrm{C}, 60^{\circ} \mathrm{C}, 80^{\circ} \mathrm{C}$, and $100{ }^{\circ} \mathrm{C}$ for $30 \mathrm{~min}$, cooled to room temperature and hemagglutination activity was determined.

\section{Effect of $\mathrm{pH}$ on the hemagglutinating activity of lectin}

In order to study the effect of $\mathrm{pH}$, buffers of varying $\mathrm{pH}$ values 6.0 , $6.5,7.0,7.5$, and 8.0 were prepared. $20 \mu \mathrm{l}$ each of the buffer was mixed with an equal volume of lectin sample in PBS. The samples were incubated overnight and the hemagglutination assay was performed.

\section{The effect of reducing agents on the stability of lectin activity}

Role of reducing agents was studied by incubating $15 \mu \mathrm{l}$ of lectin sample in the reducing agents, 2-Mercaptoethanol-(2-ME) and Dithiothreitol-(DTT), at concentrations $50 \mu \mathrm{M}, 100 \mu \mathrm{M}, 150 \mu \mathrm{M}, 200$ $\mu \mathrm{M}$, and $250 \mu \mathrm{M}$ and hemagglutination activity were assessed.

\section{Effect of EDTA and metal ions on the activity of lectin}

A modified method of Makarim et al. [25] was followed in the study of the effect of EDTA and metal ions on lectin activity. Lectin sample was incubated with $100 \mathrm{mmol}$ EDTA overnight at $4{ }^{\circ} \mathrm{C}$ (EDTA treated sample). Samples were dialyzed back to PBS and hemagglutination property of both samples was analyzed. Aliquots of dialyzed samples were treated with $100 \mathrm{mmol}$ of each metal ions-magnesium chloride $\left(\mathrm{MgCl}_{2}\right)$, calcium chloride $\left(\mathrm{CaCl}_{2}\right)$, manganese chloride $\left(\mathrm{MnCl}_{2}\right)$, barium chloride $\left(\mathrm{BaCl}_{2}\right)$, and ferric chloride $\left(\mathrm{FeCl}_{3}\right)$, incubated and hemagglutination activity was analyzed.

\section{Agglutination of bacteria by lectin sample}

A simplified version of the protocol described by Syed et al. [26] was followed in this study. Overnight cultures of both Gram-positive and Gram-negative bacteria were pelleted at $5000 \mathrm{rpm}, 10 \mathrm{~min}$, washed in PBS and resuspended in the same buffer to get approximately $2 \%$ suspension of each. Hemagglutination assay was carried out to assess the ability of the lectin to agglutinate bacterial cells.

\section{RESULTS}

Fourteen plants were screened for the presence of lectin in their leaves using hemagglutination assay. The leaf extract of Pimenta dioica showed the highest titer value of 2048 among other plants and was therefore selected further for lectin isolation (table 1).

The crude extract of $P$. dioica leaves was prepared in PBS as described previously and precipitated with ammonium sulphate at three different percentages of saturation: $0-30,30-60$, and 60-90. The hemagglutination titer and specific activity of the dialyzed fractions were obtained as shown in fig. 1, table 2 . 
Table 1: Hemagglutination titer of various plant extracts used for screening

\begin{tabular}{lll}
\hline S. No. & Name of the plant & Titer \\
\hline 1 & Carica papaya & 0 \\
2 & Capsicum frutesence & 0 \\
3 & Curcuma longa & 0 \\
4 & Moringa oleifera & 0 \\
5 & Acacia mangium & $53.33 \pm 15.09$ \\
6 & Peper nigram & 0 \\
7 & Coccinia grandis & 0 \\
8 & Excoecaria cochinchinensis & $64 \pm 0$ \\
9 & Manilkara zapota & $341.33 \pm 120.68$ \\
10 & Gliricidia sepium & 0 \\
11 & Bougainvillea spectabilis & $32 \pm 0$ \\
12 & Pimenta dioica & $3413.33 \pm 1182.41$ \\
13 & Hydrangea macrophyllum & $213.33 \pm 73.9$ \\
14 & Syzygium cumini & $128 \pm 0$ \\
\hline
\end{tabular}

Note-: Crude extracts of the following plants were subjected to serial twofold dilutions in PBS and then incubated in equal volumes of $2 \%$ erythrocyte suspension of the 0 blood group. The hemagglutination titer values were thus obtained. Titer values were expressed as mean \pm Standard Deviation (SD) of three parallel experiments ( $\mathrm{n}=3)$.

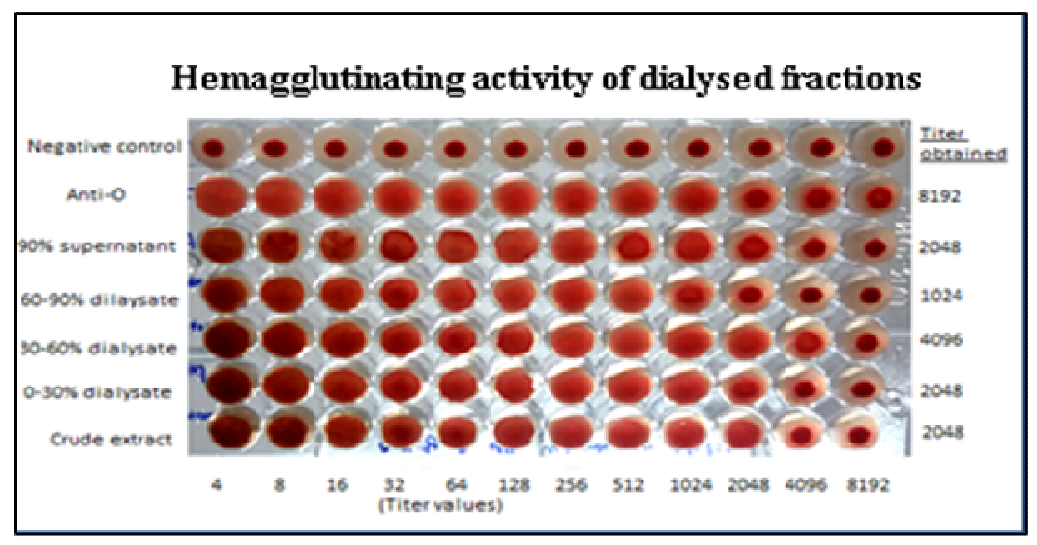

Fig. 1: Hemagglutination activity of dialyzed fractions

Note-: $50 \mu \mathrm{l}$ of each fraction was used for the assay. Anti-0 antiserum served as positive control while PBS served as a negative control

Table 2: Hemagglutination activity profile of ammonium sulphate fractions after dialysis, the values represent mean $\pm \operatorname{SD}(n=3)$. Since $p$ value $<0.05(0.022)$ there is a significant difference in specific activity $(\mathrm{HU} / \mathrm{mg})$ between different saturation of ammonium sulphate

\begin{tabular}{llll}
\hline \% saturation of ammonium sulphate & Concentration of protein used (mg/ml) & Titer (HU) & Specific activity (HU/mg) \\
\hline Crude & $0.118 \pm 0.004$ & $1707 \pm 591$ & $14476.6 \pm 5056$ \\
$0-30 \%$ & $0.13 \pm 0.007$ & $1707 \pm 591$ & $13251.3 \pm 4985$ \\
$30-60 \%$ & $0.13 \pm 0.005$ & $3413 \pm 1182$ & $25997.3 \pm 8338$ \\
$60-90 \%$ & $0.113 \pm 0.002$ & $853.3 \pm 296$ & $7607.4 \pm 2703$ \\
$90 \%$ supernatant & $0.128 \pm 0.004$ & $1707 \pm 591$ & $13257.5 \pm 4272$ \\
\hline
\end{tabular}

All dialyzed samples could agglutinate $2 \%$ human erythrocyte suspension. But the 30-60\% fraction exhibited more specific activity in agglutination.

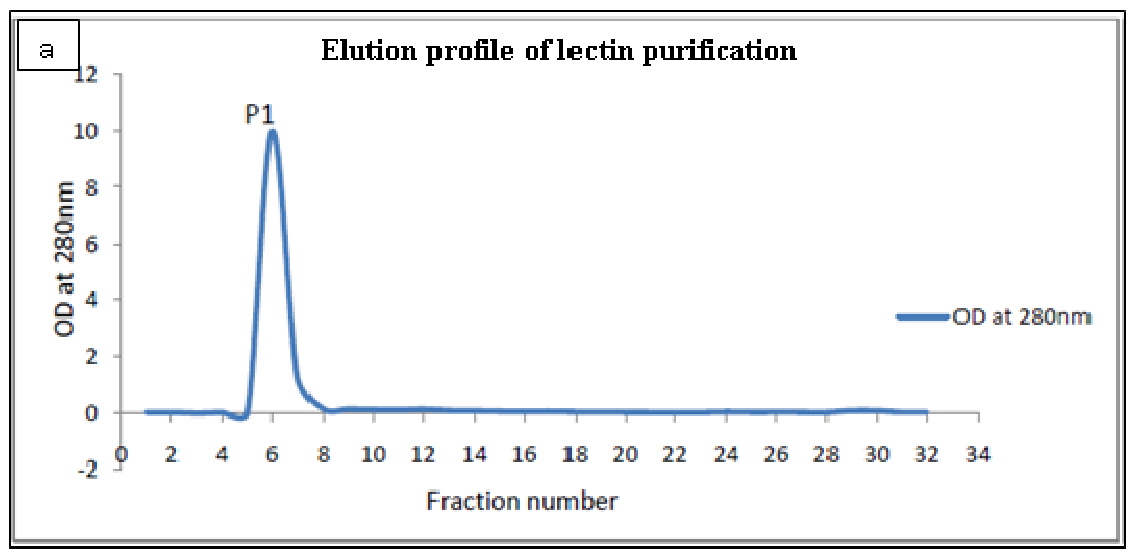




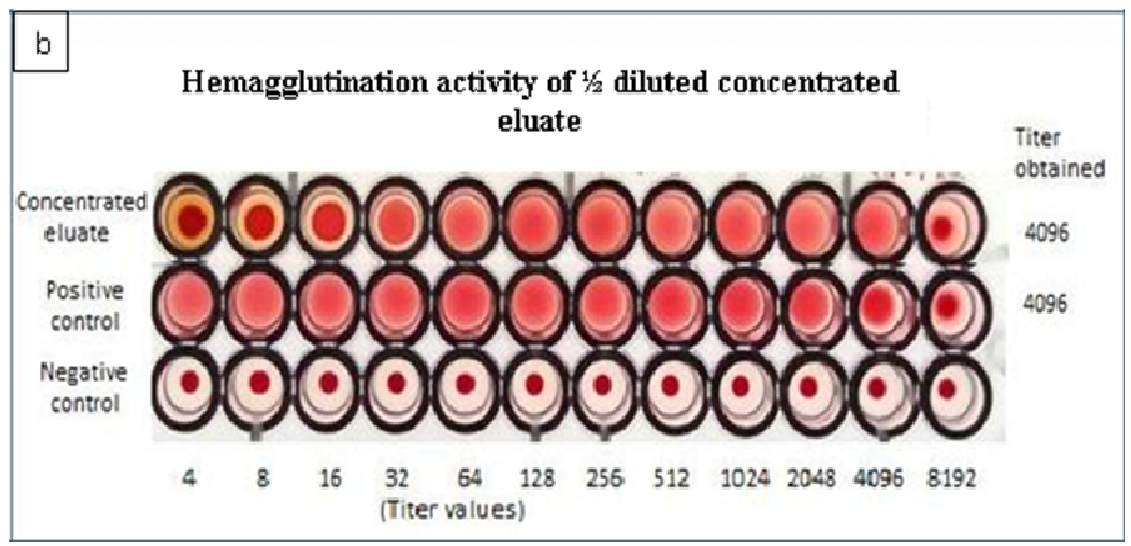

Fig. 2: Purification of lectin by Cation-exchange chromatography. (a) Lectin eluted as a single peak (P1) from Carboxy Methyl (CM) cellulose column when Glycine- $\mathrm{NaOH}$ buffer containing $0.1 \mathrm{M} \mathrm{NaCl}$ was used as eluent (b) Hemagglutination activity of the eluted column fraction after concentration. The doubly diluted fraction was used for hemagglutination study. 30-60\% dialysate served as positive control and PBS served as a negative control

The salt precipitated fraction was dialyzed in the Gly-NaOH buffer of $\mathrm{pH}$ 8.6 and was applied to the Carboxy Methyl (CM) cellulose column. Lectin eluted as a single peak with $0.1 \mathrm{M}$ sodium chloride prepared in the same buffer (fig. 2a). The dialyzed column fraction corresponding to Peak 1 gave a hemagglutination titer of 256, thus confirming the presence of agglutinins in the eluted fraction. The concentration of the fraction with Amicon Ultra-4 10K Centrifugal Filter Devices (molecular weight cut off$10 \mathrm{kDa}$ ) gave a titer value of 8192 (fig. 2b).

Table 3: Purification profile of a lectin from Pimenta dioica, the table includes data expressed as mean \pm SD where the number of experiments was three $(n=3)$

\begin{tabular}{|c|c|c|c|c|c|c|c|c|}
\hline Sample & $\begin{array}{l}\text { Concentration of } \\
\text { protein }(\mathrm{mg} / \mathrm{ml})\end{array}$ & $\begin{array}{l}\text { Titer } \\
\text { (HU/ml) }\end{array}$ & $\begin{array}{l}\text { Specific } \\
\text { activity } \\
\text { (HU/mg) }\end{array}$ & $\begin{array}{l}\text { Total } \\
\text { protein } \\
\text { (mg) }\end{array}$ & $\begin{array}{l}\text { Yield of } \\
\text { protein } \\
(\%)\end{array}$ & $\begin{array}{l}\text { Total activity } \\
\text { (HU) }\end{array}$ & $\begin{array}{l}\text { Yield of } \\
\text { activity } \\
(\%)\end{array}$ & $\begin{array}{l}\text { Fold of } \\
\text { purificat } \\
\text { ion }\end{array}$ \\
\hline Crude & $0.118 \pm 0.004$ & $1707 \pm 591$ & $14476.6 \pm 5056$ & $338.5 \pm 17$ & $100 * \pm 0$ & $4851723 \pm 1541301$ & $100 * \pm 0$ & $1 * \pm 0$ \\
\hline $\begin{array}{l}30-60 \% \text { ammonium } \\
\text { sulphate precipitate }\end{array}$ & $0.13 \pm 0.005$ & $3413 \pm 1182$ & $\begin{array}{l}25997.3 \pm 833 \\
8\end{array}$ & $\begin{array}{l}18.25 \pm 0 \\
71\end{array}$ & $5.4 \pm 0.5$ & $477866 \pm 165538$ & $9.8 \pm 0.4$ & $1.8 \pm 0.12$ \\
\hline $\begin{array}{l}\text { Ion exchange } \\
\text { chromatography }\end{array}$ & $0.089 \pm 0.009$ & $\begin{array}{l}13653 \pm 473 \\
0\end{array}$ & $\begin{array}{l}157494 \pm 648 \\
33\end{array}$ & $\begin{array}{l}1.246 \pm 0 \\
13\end{array}$ & $\begin{array}{l}0.367 \pm 0 \\
03\end{array}$ & $191392 \pm 66429$ & $4.5 \pm 2.8$ & $12 \pm 8.08$ \\
\hline
\end{tabular}

aTiter is defined as the highest dilution of the lectin solution that shows detectable agglutination. It is expressed as Hemagglutination units/ml (HU/ml), *Values taken arbitrarily.

Yield of protein $=\frac{\text { Total protein content of purified fraction }}{\text { Total protein content of the crude extract }} \times 100$

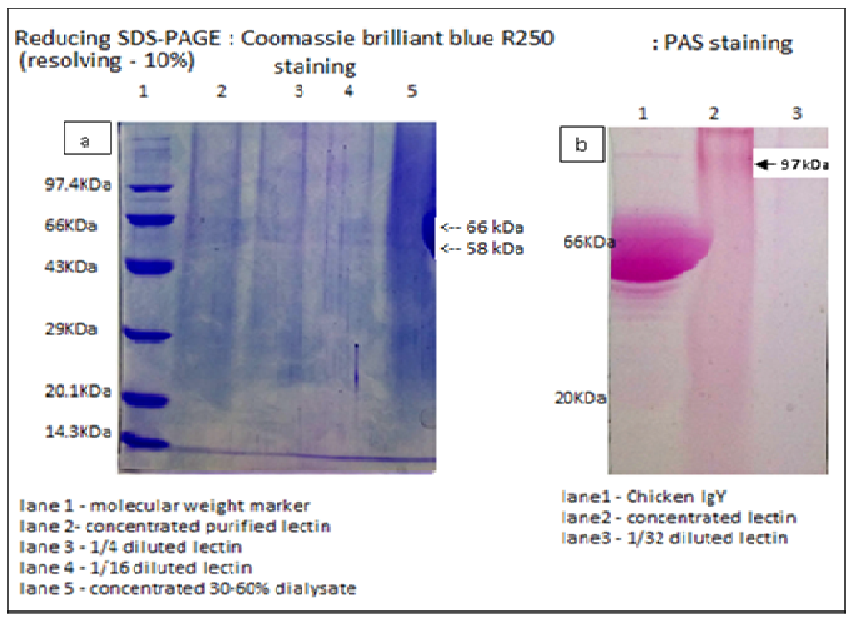

Fig. 3: Polyacrylamide gel electrophoresis of purified lectin under reducing conditions. (a) Gel stained with Coomassie brilliant blue-R250 showing 2 prominent bands of molecular weight $66 \mathrm{kDa}$ and $58 \mathrm{kDa}$. (b) PAS staining of a replica of the gel showing a band of molecular weight $\sim 97 \mathrm{kDa}$ just below the resolving gel and a smear following that
Fold of purification $=\frac{\text { Specific activity of the purified fraction }}{\text { Specific activity of the crude extract }} \times 100$

In the study of hemagglutination on the electrophoresed gel, RBC agglutination occurred in an area corresponding to the four discrete bands in the silver stained gel in the range of 43-66 kDa. The observation was comparable to that from the ultra-sonication studies (data not shown). Also, a single prominent band appeared in non-reducing SDS-PAGE (molecular weight $>97 \mathrm{kDa}$ ). Based on this, it could be concluded that the Pimenta dioica leaf lectin is a tetramer with the subunits of molecular weights $43 \mathrm{kDa}, 50 \mathrm{kDa}$, $58 \mathrm{kDa}$ and $66 \mathrm{kDa}$.

\section{Polyacrylamide gel electrophoresis of purified lectin}

The bands of molecular weight $66 \mathrm{kDa}$ and $58 \mathrm{kDa}$ occurred both in Coomassie brilliant blue-R250 staining and in silver staining. The other bands though appeared in the Coomassie-stained gel were not distinguishable as discrete bands but showed a smeared pattern. The corresponding gel area in PAS staining confirmed the presence of glycosylation as it presented a pinkish smear (fig. 3 and 4).

\section{Determination of the sugar specificity of purified lectin}

Out of the various sugars tested, mannitol, rhamnose, D-arabitol, mannose, D-melibiose, N-acetyl Galactosamine, fucose, N-acetyl Glucosamine, Xylose, lactose, fructose, sorbitol, D-arabinose, and Dgalactose, only Mannose and Xylose showed complete inhibition of agglutination at a concentration of $125 \mathrm{mmol}$ (fig. 5a). 


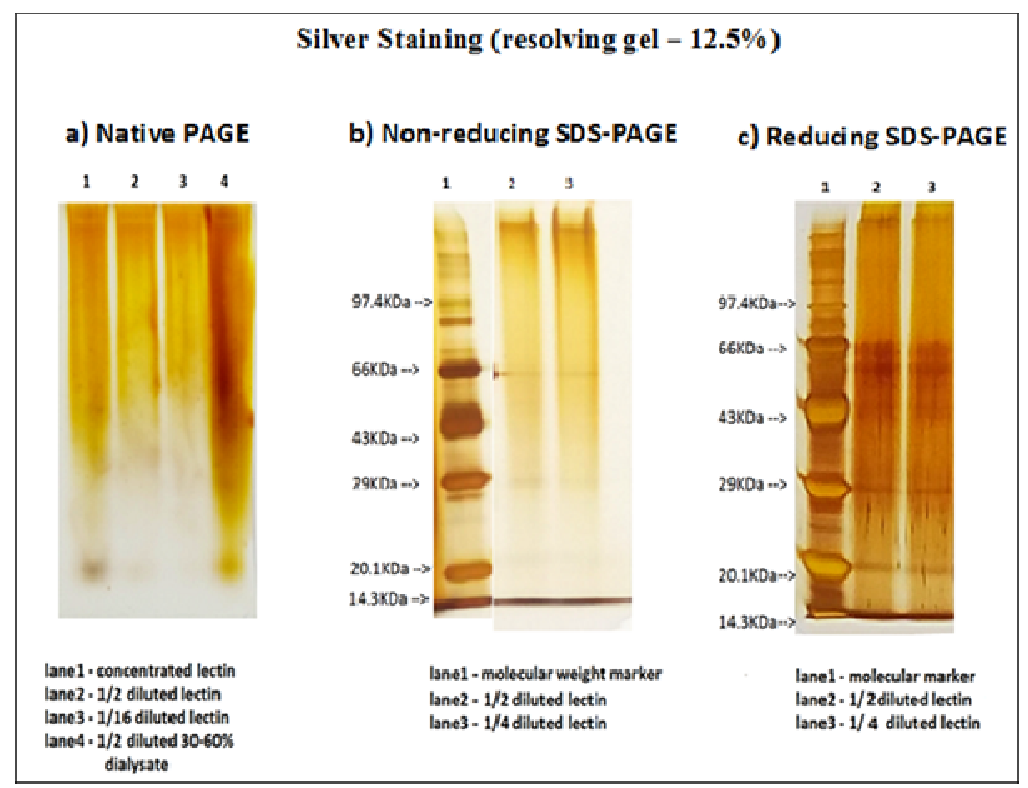

Fig. 4: Silver staining of purified lectin under various electrophoresis conditions. (a) Native PAGE shows mostly smeared appearance of the protein with a faint band at the top of the gel just below the resolving gel. (b) Non-reducing SDS-PAGE with a diffuse band at the top of the gel with a molecular weight greater than $97 \mathrm{kDa}$. (c) Reducing SDS-PAGE showed 4 discrete bands of molecular weight in the range 43$66 \mathrm{kDa}$ as marked in the fig.
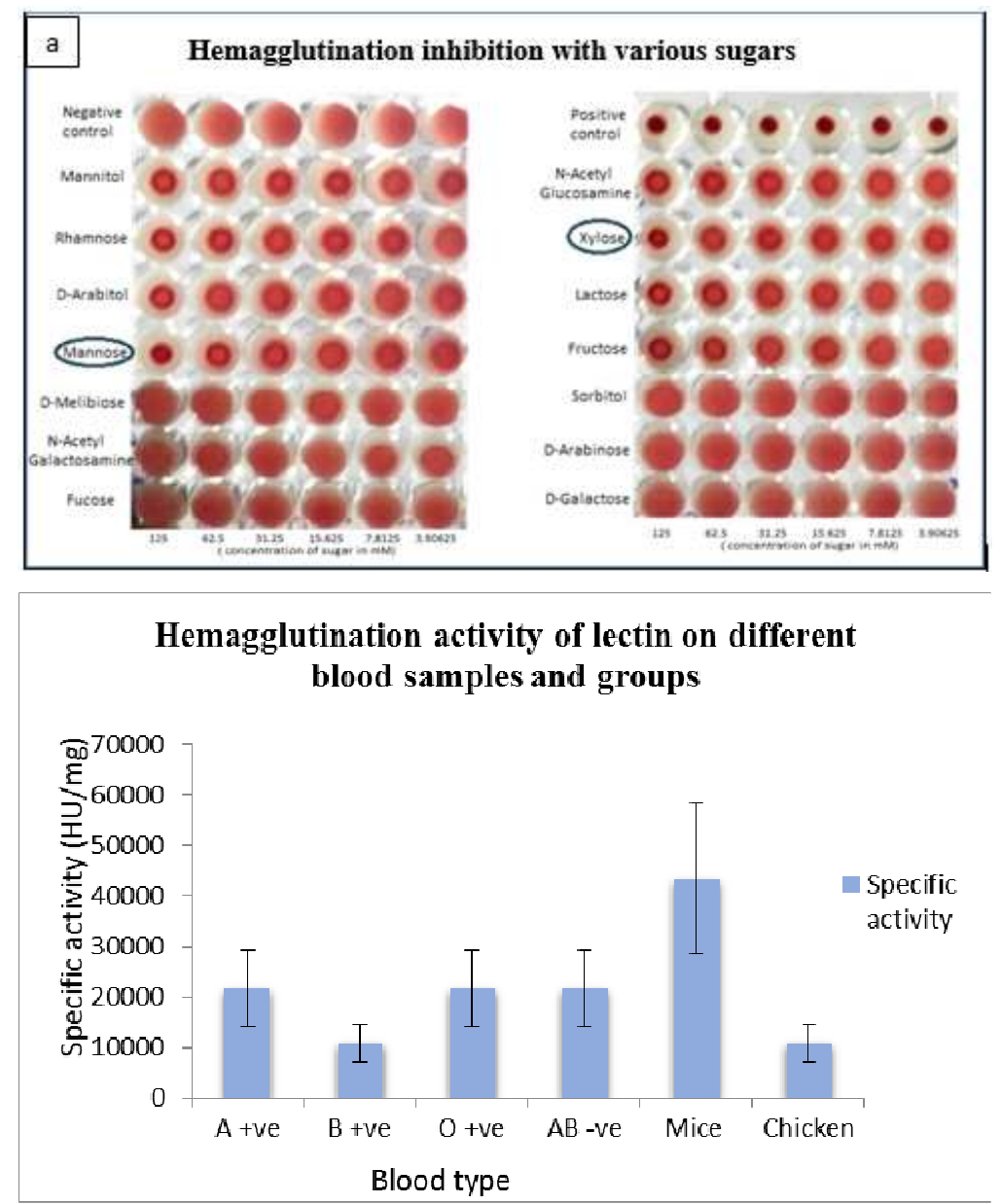

Fig. 5: Specificity of lectin towards various sugars and different blood samples. (a) Inhibition of hemagglutination with various sugars: Serial double dilutions of various sugars were prepared in microtiter plate, incubated with lectin and RBCs as described previously and observed for inhibition of hemagglutination (b) Determination of the specificity of lectin towards RBC agglutination: Various blood types including human, mouse and chicken RBCs were tested with the lectin. The specific activity of lectin towards each blood types and groups were expressed as mean \pm SD (number of experiments $=3$ ) 


\section{Blood group specificity of isolated lectin}

The lectin sample could agglutinate all the blood types tested, but more specific activity was obtained with mice erythrocytes. (fig. 5b).

Determination of the stability of lectin activity in different conditions

The purified lectin was stable in the temperature range- $20{ }^{\circ} \mathrm{C}$ to $60{ }^{\circ} \mathrm{C}$ but the activity decreased drastically at higher temperatures. Lectin also maintained the hemagglutination property in the selected $\mathrm{pH}$ range. The reducing agent's 2-beta-mercaptoethanol (2-ME) and dithiothreitol (DTT) neither improved nor decreased the hemagglutination activity of lectin. Overnight treatment of the lectin with $100 \mathrm{mmol}$ EDTA at $4{ }^{\circ} \mathrm{C}$ lowered the specific activity by half, but the removal of EDTA through dialysis could not restore its activity (fig. 6).

\section{Effect of metal ions on lectin activity}

Aliquots of dialyzed samples were treated separately with each of the metal ions-magnesium chloride $\left(\mathrm{MgCl}_{2}\right)$, calcium chloride $\left(\mathrm{CaCl}_{2}\right)$, manganese chloride $\left(\mathrm{MnCl}_{2}\right)$, barium chloride $\left(\mathrm{BaCl}_{2}\right)$, and ferric chloride $\left(\mathrm{FeCl}_{3}\right)$ at a concentration of $100 \mathrm{mmol}$, incubated at room temperature for $2 \mathrm{~h}$ and hemagglutination activity was analyzed. It was observed that none of the ions, except $\mathrm{MgCl}_{2}$, have a role in hemagglutination. Instead, they were able to give hemagglutination by themselves. But treatment with $\mathrm{MgCl}_{2}$ reduced the specific activity of lectin by half.

Detection and estimation of total carbohydrates in the lectin sample

Molish test was performed to qualitatively detect the presence of carbohydrates in the sample which was positive with the appearance of a red ring. The total carbohydrate in the lectin sample was estimated by Anthrone method as described previously. $60 \pm 14.1 \mu \mathrm{g}(0.06 \pm 0.014 \mathrm{mg})$ of glucose equivalents were found per $300 \mu \mathrm{g}$ of a lectin that is about $20 \%$ carbohydrate by weight.

\section{Agglutination of bacteria by purified lectin}

Both Gram-positive and Gram-negative species (Staphylococcus aureus, Escherichia coli, Klebsiella pneumonia, Proteus vulgaris, Pseudomonas aeruginosa, Salmonella typhi) were tested for its ability to get agglutinated in the presence of the purified lectin. After careful observation, it was inferred that only the Gram-negative Escherichia coli and Proteus vulgaris were positive for agglutination.
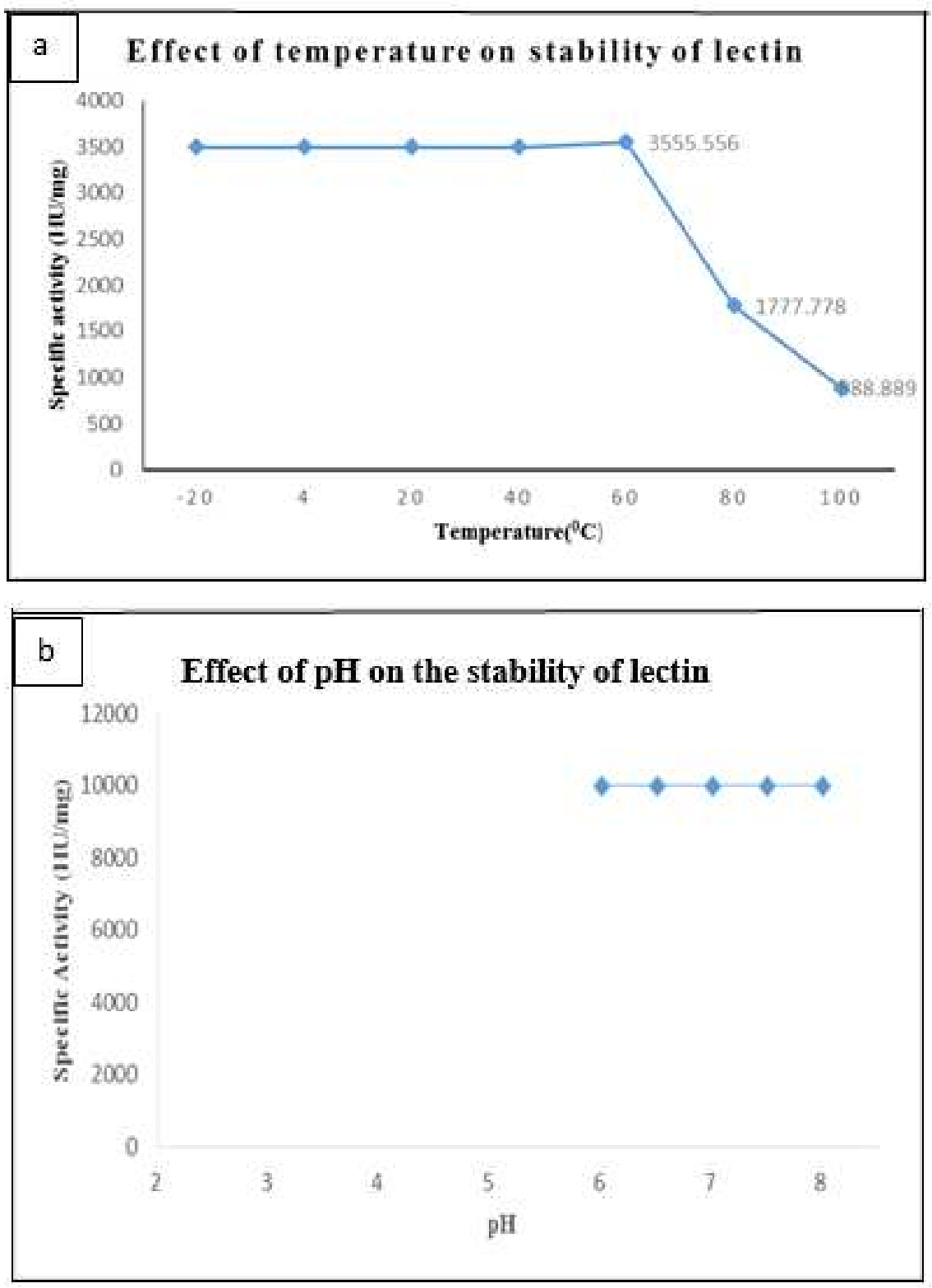

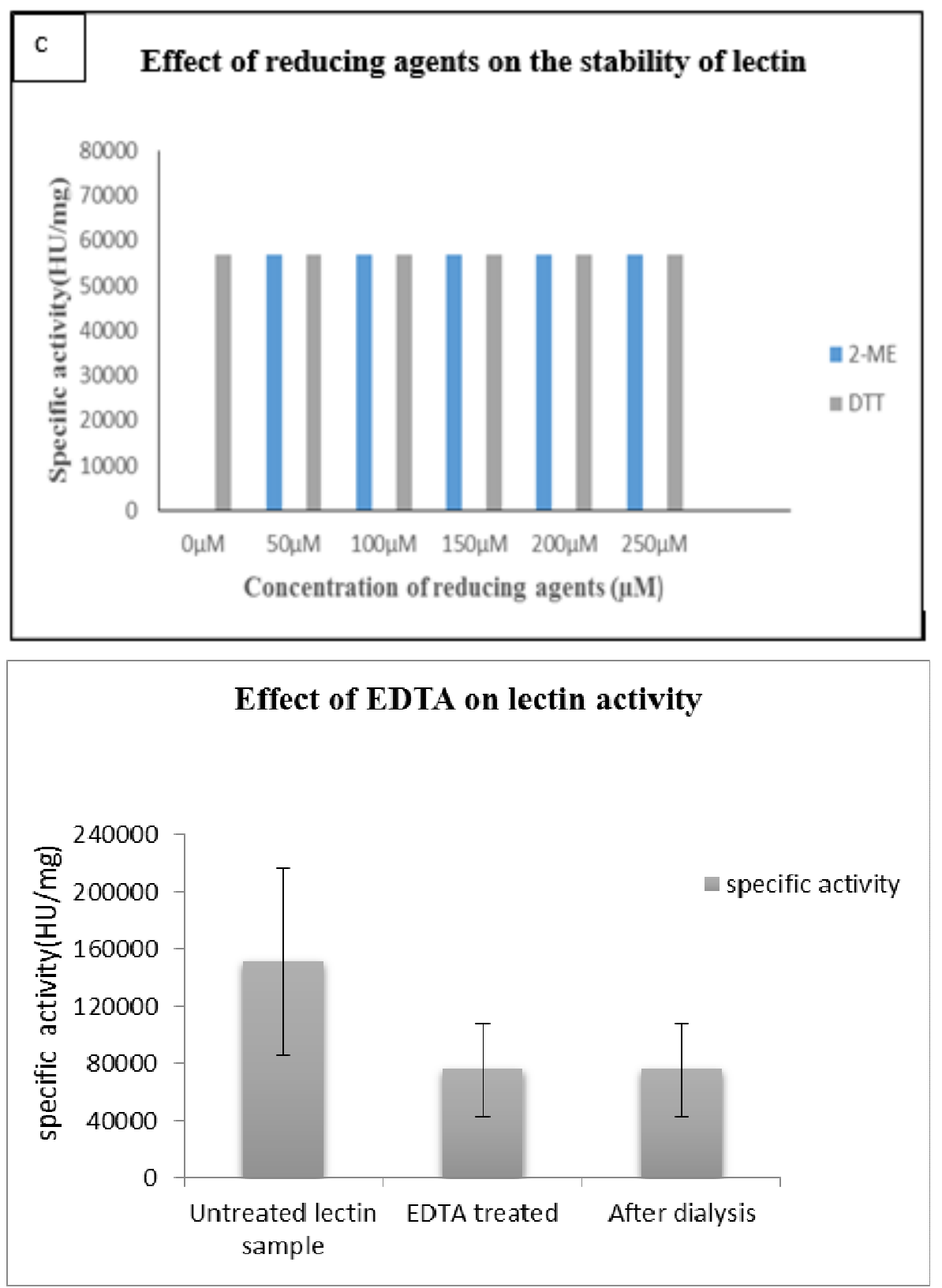

Fig. 6: Determination of the stability of lectin under various conditions. (a) Effect of temperature on the stability of lectin: Lectin sample was incubated at different temperature for $30 \mathrm{~min}$ and cooled to room temperature and hemagglutination activity was analyzed. (b) Stability of lectin in the $\mathrm{pH}$ ranges 6.0-8.0: Lectin sample was incubated overnight at $4{ }^{\circ} \mathrm{C}$ with phosphate buffer at different pH ranging from 6 to 8 and hemagglutination activity was determined. (c) Effect of reducing agents on the stability of lectin: 2-beta-mercaptoethanol and dithiothreitol were used as reducing agents at a concentration of 50 $\mu \mathrm{M}-250 \mu \mathrm{M}$. $0 \mu \mathrm{M}$ refers to $1 / 8$ diluted column fraction without any reducing agents. (d) Effect of EDTA treatment on lectin activity: lectin was subjected to overnight incubation with $100 \mathrm{mmol}$ EDTA at $4{ }^{\circ} \mathrm{C}$ followed by EDTA removal through dialysis. The specific activity of lectin in different treatment conditions was expressed as mean $\pm \operatorname{SD}(n=3)$

Table 4: Agglutination of bacteria by purified lectin

\begin{tabular}{llll}
\hline Bacteria tested & Agglutination & Titer & Specific activity \\
\hline Escherichia coli & + & $2731 \pm 1182$ & $151317 \pm 65522$ \\
Klebsiella pneumoniae & - & 0 & - \\
Staphylococcus aureus & - & 0 & - \\
Proteus vulgaris & + & $3413 \pm 1182$ & $189147 \pm 65522$ \\
Pseudomonas aeruginosa & - & 0 & - \\
Salmonella typhi & - & 0 & - \\
\hline
\end{tabular}

Note: Agglutination of bacteria by the purified lectin was observed. The titer values and specific activities were recorded as mean \pm SD. The experiments were repeated thrice for each bacterium. Since p $>0.05(0.519)$ there is no significant difference between $E$. coli and Proteus vulgaris. 


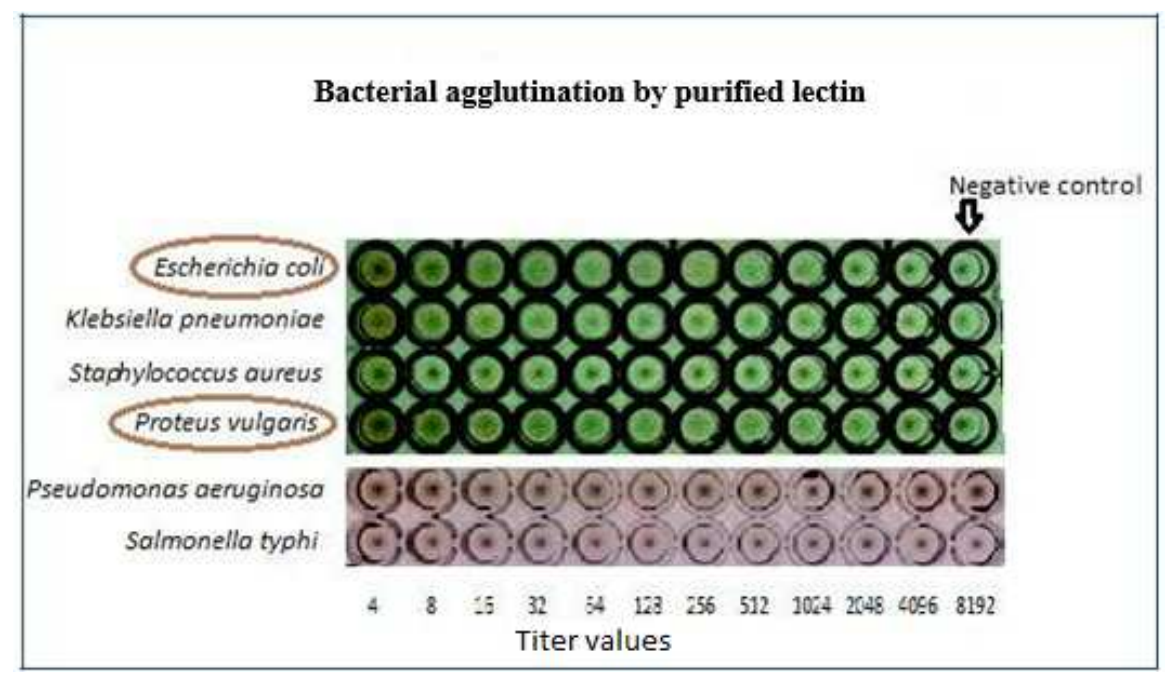

Fig. 7: Agglutination of lectin by purified lectin. The $1 / 2$ diluted lectin sample was used for the assay, the last well in each row contained no lectin and served as a negative control

\section{DISCUSSION}

Lectin activity from Pimenta dioica leaves was investigated by performing agglutination assays. Due to the presence of sugar residues on the surface of erythrocytes an interaction is formed between the lectin and these sugars resulting in agglutination. The hemagglutinating activity of Pimenta dioica was specifically inhibited by mannose and xylose suggesting that the lectin was specific for these two sugars. The lectin agglutinated all blood groups tested thus proving it to be a non-blood group specific lectin. However, it showed a higher affinity for mouse erythrocytes.

Lectin eluted as a single, prominent peak on performing cation exchange chromatography with CM Cellulose and was eluted with $0.1 \mathrm{M} \mathrm{NaCl}$ in Gly-NaOH buffer. The fast elution of the lectin might be due to the weak interactions with the resin. Hence future efforts are needed which comprises of an affinity column chromatography that would be highly specific to the lectin under study. The highly purified and concentrated lectin could be examined for various biological activities including antifungal activity, cytotoxic assays, anti-insect activity and anti-neoplastic activity. The appearance of a pinkish smear in PAS staining confirmed the presence of glycosylation in the purified lectin sample thus indicating it to be a glycoprotein. The difference in the extent of glycosylation might be a reason of the smeared pattern of the protein fractions in polyacrylamide gels as it interacts differently with SDS. Presence of carbohydrate in the lectin sample was further confirmed by Molish test and estimated via Anthrone method as $60 \pm 14.1 \mu \mathrm{g}(0.06 \pm 0.014$ $\mathrm{mg}$ ) of glucose equivalents per $300 \mu \mathrm{g}$ of lectin sample. Most lectins are tetramers made up of nearly four identical subunits. In the present investigation, the purified lectin appeared as 4 discrete bands comprising of molecular weight in the range of $43-66 \mathrm{kDa}$.

Cooperative hydrogen bonding, in which the hydroxyl group $(\mathrm{OH})$ acts simultaneously as a hydrogen-bond donor and acceptor, is characteristic of the interaction of most lectins and other carbohydrate-binding proteins with sugar hydroxyls [27]. Due to these effects, many multi-branched oligosaccharides exhibits stronger lectin binding activity and some lectins possess dual or multiple affinities for different disaccharides which is essentially hydrophobic [28]. The study shows that xylose and mannose could interact with the lectin under study inhibiting its hemagglutination property.

Lectins are relatively resistant to both heat (at $70{ }^{\circ} \mathrm{C}$ more than 30 min) and some are highly resistant to gastric acid and proteolytic enzymes [29]. The lectin in the present study retained its agglutination property in the $\mathrm{pH}$ range 6-8 and was stable in the temperature range of $20^{\circ} \mathrm{C}-60^{\circ} \mathrm{C}$ for a period of $30 \mathrm{~min}$. The reducing agents such as $2-\mathrm{ME}$ and DTT at a $50-250 \mu \mathrm{M}$ concentration, neither improved nor decreased the hemagglutination activity of lectin. Ethylenediaminetetraacetate (EDTA) is a chelator of the metal ion. In the present study, incubation with EDTA reduced the lectin activity which can be related to the requirement of the metal ion for hemagglutination. But, as the removal of EDTA through dialysis could not restore the lectin activity, it can be concluded that the ions inherent in the buffer system are not itself playing a vital role in hemagglutination. The metal ions $\mathrm{MgCl}_{2}, \mathrm{CaCl}_{2}, \mathrm{MnCl}_{2}, \mathrm{BaCl}_{2}$, and $\mathrm{FeCl}_{3}$ at $100 \mathrm{mmol}$ concentration had no effect on lectin activity. But treatment with $\mathrm{MgCl}_{2}$ reduced the specific activity of lectin by half. This might be because of either $\mathrm{MgCl}_{2}$ competing with lectin for $\mathrm{RBC}$ surface receptors or it is binding to lectin domains blocking carbohydrate recognition.

$P$. dioica berries are reported to contain phenylpropanoids, glycosides, tannins and essential oil while the leaf is reported to contain Eugenol, Methyl Eugenol, $\beta$-caryophyllene and Myrcene. The anticancer, anti-microbial, anti-insect, nematicidal, and anti-oxidant studies of the Pimenta extract have already been reported [30]. Studies on the plants of Solanum genus have been assessed for its potential antimicrobial and anticancer activity [31]. Hence it would be beneficial if studies are conducted on the anticancer activity of $P$. dioica lectin. This would be the first study to isolate a lectin from the leaves of $P$. dioica with the ability to agglutinate bacteria. Previous research has revealed that plant lectins interact with bacteria [32]. Although lectin could potentially agglutinate Escherichia coli and Proteus vulgaris, growth inhibition was not accompanied even when double the concentration of the lectin was used. Hence it can be concluded that $P$. dioica lectin possesses a bacteriostatic effect rather than a bactericidal effect on the tested strains as reported earlier by Makarim et al. in the case of EMtL6, a lectin from Tamarindus indica. Lectins do not cause any antigenic stimulation within the immune system, but they have the basic capacity to bind analogously to an antibody [33]. The carbohydrates present on the bacterial cell wall such as muramic acid and $\mathrm{N}$-acetylmuramic acid bind to the lectins as reported earlier $[34,35]$. The ability of the lectin to form complexes with microbial glycoconjugates can be explored for potential drug targets [36]. This particular study opens up a new and exciting area of lectin-based therapeutics in the coming future.

\section{CONCLUSION}

Leaves of Pimenta dioica (L.) Merr are found to be a good source of lectin with significant hemagglutination activity. The lectin was purified partially by cation exchange chromatography when glycine$\mathrm{NaOH}$ was used as the buffer system and was found to contain nearly $20 \%$ carbohydrates. The activity of the lectin did not exhibit any specificity to human, mice or avian erythrocytes and was nearly independent of metal ions. The purified lectin was stable up to $60^{\circ} \mathrm{C}$ 
and was not affected by either 2-ME or DTT at $50-250 \mu \mathrm{M}$ concentration. Lectin activity was completely inhibited by xylose and mannose at a concentration of $125 \mathrm{mmol}$. The purified lectin agglutinated the Gram-negative Escherichia coli and Proteus vulgaris showing its potential to be used for bacterial typing and for the designing of bacterial filters. Bacterial agglutination can also be exploited to increase the particle size of bacteria to be easily recognized by the immune system. The research can be extended further with the exploration of more applications and utilities of Pimenta dioica (L.) Merr leaf lectin.

\section{ACKNOWLEDGEMENT}

Department of Biotechnology, Government of India for the financial support.

Malabar Institute of Medical Science (MIMS) Hospital, Calicut for kindly providing the blood for the purpose of hemagglutination studies.

\section{AUTHORS CONTRIBUTIONS}

SURYA PH: Data collection, Design of the work, and writing the manuscript.

\section{ELYAS K K: Critical revision of the article and Proofreading.}

DEEPTI MADAYI: Data analysis, Proofreading, Revision and final approval of the article to be published.

\section{CONFLICT OF INTERESTS}

Declared none

\section{REFERENCES}

1. Boyd WC, Shapleigh E. Specific precipitating activity of plant agglutinins (lectins). Science 1954;119:419.

2. Goldstein IJ, Hughes RC, Monsigny M, Osawa T, Sharon N. What should be called a lectin? Nature 1980;2:285-66.

3. Sharon N, Lis H. History of lectins: from hemagglutinins to biological recognition molecules. Glycobiology 2004;11:53R-62R.

4. Rabia Hamid, Akbar Masood, Ishfak H Wani, Shaista Rafiq. Lectins: proteins with diverse applications. J Appl Pharm Sci 2013;3(4, Suppl 1):S93-S103.

5. Agrawal BBI, Goldstein IJ. Specific binding of Concanavalin A to cross-linked dextran gels. Biochem J 1967;96:23C-15C.

6. Goldstein IJ. Lectin structure-activity: the story is never over. J Agric Food Chem 2002;50:6583-5.

7. Kumar KK, Lalith Prakash CK, Sumanthi J, Reddy GS, Shekar PC, Reddy B. Biological role of lectins: a review. J Orofac Sci 2012;4:20-5.

8. Nicolson GL, Blaustein J, Etzler ME. Characterization of two plant lectins from Ricinus communis and their quantitative interaction with a murine lymphoma. Biochemistry 1974; 13:196-204.

9. Lis H, Sharon N. Lectins in higher plants. In: Marcus A. Ed. The Biochemistry of Plants. Vol. 6. New York; Academic Press: 1981. p. 371-447.

10. Selitrennikoff CP. Antifungal proteins. Appl Environ Microbiol 2001;67:2883-94.

11. Keyaerts, Vijgen L, Pannecouque C, Van Damme E, Peumans W, Egberink $\mathrm{H}$, et al. Plant lectins are potent inhibitors of coronaviruses by interfering with two targets in the viral replication cycle. Antivir Res 2007;75:179-87.

12. Maria A Souza, Fernanda C Carvalho, Luciana P Ruas, Rafael Ricci-Azevedo, Maria Cristina Roque-Barreira. The immunomodulatory effect of plant lectins: a review with emphasis on Artin M properties. Glycoconj J 2013;30:641-57.

13. Ramadhania ZM, Insanu M, Gunarti NS, Wirasutisna KR, Sukrasno S, Hartati R. Antioxidant activity from ten species of Myrtaceae. Asian J Pharm Clin Res 2017;10:5-7.
14. Neal MC. In Gardens of Hawai'i. Bernice P. Bishop Museum special publication 40, Bishop Museum Press: Honolulu, HI; 1965.

15. Weiss EA. Spice Crops. New York; CABI Publishing: 2002.

16. Anonymous. A wealth of India (Raw Materials). Publications Information Division, CSIR Publications. New Delhi; 1969;8:58-9.

17. Ynalvez RA, Cruz CG, Ynalvez MA. Isolation, partial purification and characterization of texas live oak (Quercus fusiformis) lectin. Adv Biosci Biotechnol 2015;6:470-84.

18. Bradford MM. A rapid and sensitive method for the quantitation of microgram quantities of protein utilizing the principle of protein-dye binding. Anal Biochem 1976;72:24854.

19. Laemmli M Favre. Gel electrophoresis of proteins. J Mol Biol 1973;80:575-99.

20. Rosenberg Ian M. Protein analysis and purification: benchtop techniques. USA; Birkhauser, Boston; 1996.

21. Sadasivam S, Theymoli Balasubramanian. Practical Manual, Tamil Nadu Agricultural University, Coimbatore; 1985. p. 2.

22. Hedge JE, Hofreiter BT. In: Whistler RL, Be Miller JN. Eds. In: Carbohydrate Chemistry, New York; Academic Press: 1962. p. 17.

23. Laija SN, Mahesh S, Smitha LS, Remani P. Isolation and partial characterization of two plant lectins. Curr Res J Biol Sci 2010;2:232-7.

24. Pla A, Alonso E, Batista-Viera F, Franco Fraguas L. Screening for carbohydrate binding proteins in extracts of Uruguayan plants. Braz J Med Biol Res 2003;36:851-60.

25. Makarim Elfadil M Osman, Amna KE Awadallah, Emadeldin Hassan E Konozy. Isolation, purification and partial characterization of three lectins from tamarindus Indica seeds with a novel sugar specificity. Int J Plant Res 2016;6:13-9.

26. Syed Rashel Kabir, Md Mahamodun Nabi, Md Nurujjaman, Md Abu Reza A HM Khurshid Alam, Rokon Uz Zaman, et al. Momordica charantia seed lectin: toxicity, bacterial agglutination and antitumor properties. Appl Biochem Biotechnol 2015;175:2616-28.

27. William I Weis. Structural basis of recognition lectincarbohydrate. Anna Rev Biochem 1996;65:441-73.

28. Timothy Richard Helliwell. Lectin methods and protocols. Methods Mol Med 1997;9:73-94.

29. Rocca JD. Lectins as next-generation mucoadhesives for specific targeting of the gastrointestinal tract. Drug Development Delivery 2004; 4:12-9.

30. Pratheeba M, Rani KU, Ramesh B. Studies on the antimicrobial and anticancer activity of Solanum trilobatium. Asian J Pharm Clin Res 2013;7:213-9.

31. Rao PS, Navinchandra S, Jayaveera KN. An important spice, Pimenta dioica (Linn.) merill a review. Int Curr Pharm J 2012;1:221-5.

32. Santi-Gadelha T, De Almeida Gadelha CA, Aragão KS, De Oliveira CC, Lima Mota MR, et al. Purification and biological effects of Araucaria angustifolia (Araucariaceae) seed lectin. Biochem Biophys Res Commun 2006;350:1050-5.

33. Komath SS, Kavitha M, Swamy MJ. Beyond carbohydrate binding: new directions in plant lectin research. Org Biomol Chem 2006;4:973-88.

34. Hirmo S, Ut M, Wadstrom T. Sialyl Glycoconjugate and proteoglycan binding microbial lectins. Electronic Lectin J: Lectins Biol Biochem Clin Biochem 1997;1287-984583-0-2.

35. Caldeon AM, Buck G, Doyle RJ. Lectin-microorganism complexes. Electronic Lectin J: Lectins Biol Biochem Clin Biochem 1997; 1287-984583-0-2.

36. Raja SB, Murali MR, Kumar NK, Devaraj SN. Isolation and partial characterization of a novel lectin from Aegle marmelos fruit and its effect on adherence and invasion of Shigellae to HT29 cells. PLoS One 2011;6:1-9. 